\title{
間欠照射と外気導入によるマイクロ波減圧乾燥の乾燥促進*
}

\author{
鶴田隆 治*1, 林伊 久*2

\section{Enhancement of Microwave Drying Under Reduced Pressure Condition by Irradiation Control and External Air Supply}

\author{
Takaharu TSURUTA*3 ${ }^{* 3}$ and Tadahisa HAYASHI \\ ${ }^{* 3}$ Department of Mechanical Engineering, Kyushu Institute of Technology, \\ 1-1 Sensui, Tobata, Kitakyushu-shi, Fukuoka, 804-8550 Japan
}

\begin{abstract}
We present a novel microwave drying as an effective drying method for seafood. Microwave is irradiated in pulse or intermittently so as to keep the temperature of material at around room temperature in a reduced pressure system. Energy of microwave is supplied just for the latent heat for evaporation. Also, by introducing a small amount of external air into the system, water vapor can be effectively carried out of the drying system. We made several experiments using the scallop as seafood. The drying time was successfully shortened as compared with the warm-air drying and the drying at room-temperature results in good quality for dried seafood. Microphotographs of scallop indicate us that the morphological change of the muscular fiber-cells has an important role in water transport. The present drying method prevent from the cell shrink at the scallop surface observed in the warm-air drying, but keep the channel for water transportation to the outside. The new method is proved to be an effective and applicable way of seafood drying.
\end{abstract}

Key Words: Drying Enhancement, Microwave Drying, Reduced Pressure, Air Ventilation

\section{1. 緒論}

乾燥技術は幅広い分野において用いられるが，そ の多くはいわゆる温風乾燥である. しかしながら, 特 に海産物や野菜などの食材の温風乾燥においては, 脂 質変化やたんぱく質の変性, 乾燥ムラ, 変色や割れな どの品質の劣化が生じやすいため, 温風温度を低温に せざるを得ず, 長時間の乾燥を余儀なくされている. 一方, 品質を重視した凍結真空乾燥も最近では多用さ れているが, 水からの昇華に時間を要することや, 乾 燥法の中で最も高価な方法であるなどの課題も多く, 高品位で，かつエネルギー利用効率の高い乾燥技術を 開発する努力がなされている(1-4).

著者らは，ホタテ貝柱を対象とした温風乾燥実験 を行い，貝柱を構成する筋繊維組織の観察を通して生 体としての内部乾燥機構について検討している(5). そ の結果, 温風乾燥では外部からの加熱であるが故に, 表面層の乾燥による収縮が内部からの水分流路を狭め ること,および温度上昇による細胞内外の浸透圧増大

* 原稿受付 2005 年 10 月 20 日.

*1 正員, 九州工業大学工学部( 804-8550 北九州市戸畑区仙 水町 1-1).

*2 正員, 福岡工業技術センター (- $807-0831$ 北九州市八幡西 区則松 3-6-1).

E-mail : tsuruta@ mech.kyutech.ac.jp
によって筋繊維が膨閏し，筋繊維間の水分流路が狭く なって物質移動の抵抗が増大寸ることを示している. これらの抵抗が, 減率乾燥期間において乾燥速度を遅 くすることになる.

本論文は, 温風乾燥において得られたこれらの知 見に基づき，マイクロ波による水一の選択的エネルギ 一供給と減圧環境による蒸発温度の低下を特長とした マイクロ波減圧乾燥法に着目して, 高品位・高速乾燥 のための新たな提案を行うものである. 具体的には, 減圧とマイクロ波の間久的照射によって常温乾燥を実 現すること, ならびに乾燥装置内に少量の気体を流入 させることによって, 蒸発した蒸気を効率的に乾燥装 置外に排出することによる. これまでにもマイクロ波 の間欠あるいはパルス照射を行った減圧乾燥の例(69) はあるが，気体導入を組み合わせた例は無いようであ る. 本報では, 海産物としてホタテ貝柱を使った実験 を行い，新しい乾燥方法が海産物の乾燥に対して有効 な方法であることを示す.

\section{2. 実験装置および方法}

実験装置の概略を図 1 に示寸. 内径 $100 \mathrm{~mm}$, 高さ 70mm の円筒形をした石英ガラス製真空乾燥室を電子 レンジの庫内に設置し，これを一定の圧力に減圧する 


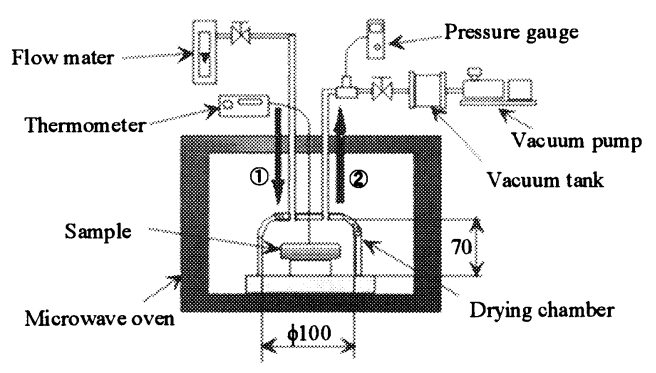

Fig.1 Experimental apparatus of microwave drying

ための真空タンクと真空ポンプからなる排気系に接続 するとともに, 乾燥室内に一定量の気体を導入するた めの導入系とからなっている. 電子レンジには, $325(\mathrm{~W}) \times 370(\mathrm{D}) \times 240(\mathrm{H})$ の加熱室を有し，700W，500W, 200W および 100W の 4 種類のマイクロ波照射を行え る業務用電子レンジを使用した.ここで， $700 \mathrm{~W}$ と 500W の出力は連続照射によって得られるが, その他 の出力は一定の間欠的なパルス照射により調整されて いる. 本研究では, 基本照射パターンとして $100 \mathrm{~W}$ 出 力を使用し，そのパルス間隔を変えることにより $100 \mathrm{~W}$ より低い平均出力を設定した. 図 2 にその照射 パターンを示す．基本照射パターンの $100 \mathrm{~W}$ では, 約 8 秒間の照射が 25 秒の間隔をおいて行われるが, そ の間隔を 32 秒， 36 秒，72 秒と長くすることにより， $83 \mathrm{~W} ， 75 \mathrm{~W}$ と $42 \mathrm{~W}$ の平均照射量としている. また, 照射の ON-OFF 操作により, ホタテ貝柱の中心部温度 を $30 \sim 40^{\circ} \mathrm{C}$ 範囲で一定に保つ温度制御実験も行っ ている. なお, これらの照射量の数值は, 電子レンジ の能力を表すいわば公称值であり，試料に実際に投入 されるエネルギー量とは異なるものであるが，両者は ほぼ比例関係にあると考える。

試料には，平均径が約 $36 \mathrm{~mm}$ ，平均高さが約 $18 \mathrm{~mm}$ で，平均質量がおよそ $25 \mathrm{~g}$ のホタテ貝柱を使用し，1 個を乾燥室の中央底部に置いた. 乾燥室内の圧力は, $6.66 \mathrm{kPa}(50 \mathrm{mmHg})$ を基本とし， $13.2 \mathrm{kPa}(100 \mathrm{mmHg})$ と $20 \mathrm{kPa}(150 \mathrm{mmHg})$ の 3 条件とした. 導入する気体には 外気を標準とし， $0.5 \mathrm{~L}_{N} / \mathrm{min}$ および $2 \mathrm{~L}_{\mathrm{N}} / \mathrm{min}$ の流量で乾 燥容器内に流入させた. また, 非酸化雰囲気とすると ともに導入する気体の湿分を完全に排除するために, 窒素ガスを導入する実験も実施した. なお，実験は室

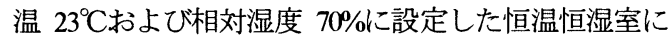
て行った. ホタテ貝柱の温度の過度変化は, ホタテ貝 柱の中心部と表面に取り付けた 2 本の蛍光式光ファイ バー温度計で測定した.この光ファイバー温度計は, マイクロ波照射下において温度センサーとして使用す

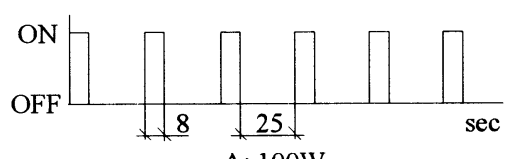

A: $100 \mathrm{~W}$

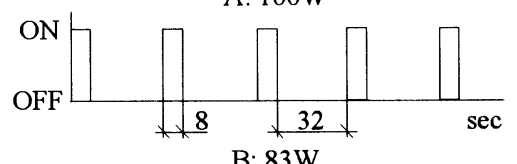

B: $83 \mathrm{~W}$

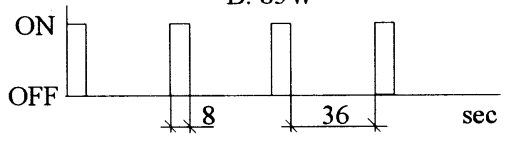

C: $75 \mathrm{~W}$

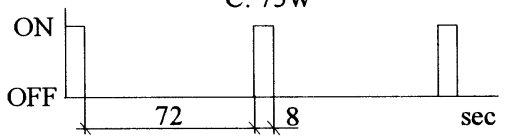

D: $42 \mathrm{~W}$

Fig. 2 Pulse-type irradiation pattern of microwave

ることが可能である. 含水率と蒸発速度は, 10 分毎 にホタテ貝柱を取り出して質量を測定することから求 めた. また，内部の水分分布の測定も温風乾燥で行っ た方法と同様 ${ }^{(5)}$ ，ホタテ貝柱の中央部を縦方向に約 2 〜 $3 \mathrm{~mm}$ 角で 10 等分にし, 各片の水分質量から算出 した. さらに, ホタテ貝柱内の水分移動現象を温風乾 燥の場合と比較して検討するため, 組織の顕微鏡観察 を行った. すべての実験值は，3 回の測定値の平均と した.

\section{3. 結果と考察}

$3 \cdot 1$ 温度制御実験 最初に，6.66 $\mathrm{kPa}$ の圧力条 件下において，温度制御を行った実験結果について示 す. 外気流入量は $2 \mathrm{~L} / \mathrm{min}$ とし，ホタテ貝柱の中心部

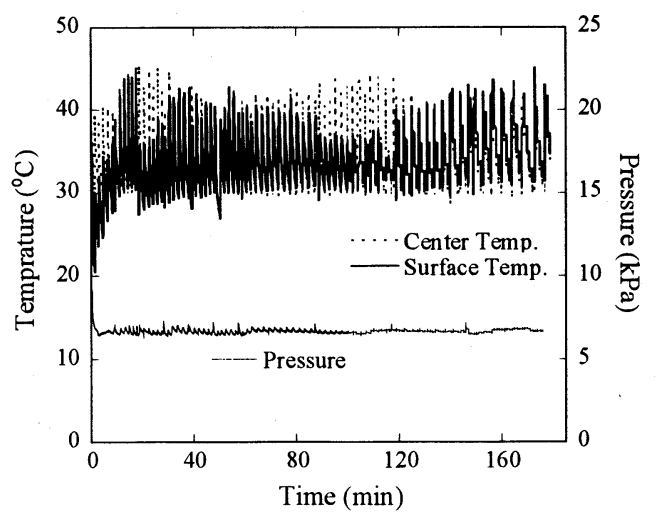

Fig.3 Temperature and pressure transients of scallop 


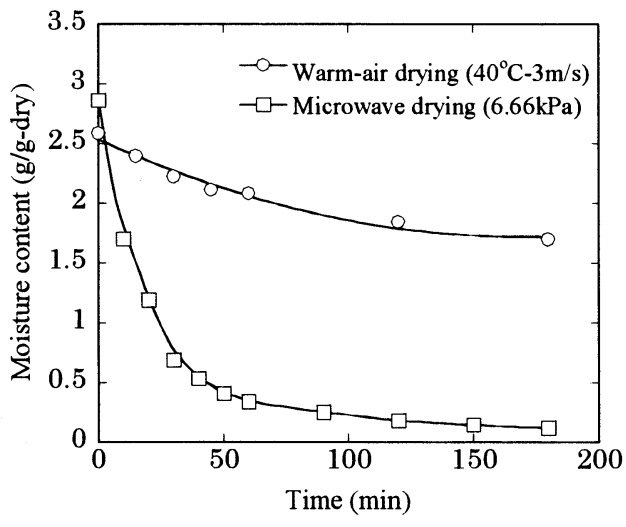

Fig. 4 Comparison of drying rate between microwave drying and warm-air drying

温度が $30 \sim 40^{\circ} \mathrm{C}$ 範囲になるように制御した. マイ クロ波の基本照射モデルは図 2-A に示す $100 \mathrm{~W}$ の場合 を用いたが，図 3 に示すように温度がおよそ $40^{\circ} \mathrm{Cを}$ 超えるとマイクロ波照射を停止し, 水分蒸発による潜

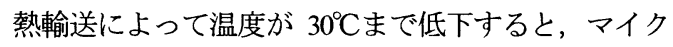
口波を再び照射した. 図 3 からわかるように, マイ クロ波照射の ON/OFF による温度変化は非常に早く， また蒸発のために表面温度が中心部よりも低くなって おり，熱と物質移動が同方向に揃う結果，エネルギー 供給と蒸発とが効果的に行われていると言える.なお, 乾燥室内の圧力には変化は見られず，一定に保たれて いる. このときの含水率の過度変化を，温風乾燥の一 例と比較して図 4 に示す. マイクロ波減圧乾燥は温風 乾燥に比べて非常に早く乾燥していることがわかる. つまり, 温風乾燥が乾燥開始後 180 分後に乾量基準の 含水率が $1.7 \mathrm{~g} / \mathrm{g}$-dry 程度までしか減少しないのに対し， マイクロ波減圧乾燥では 10 分程度でこの含水率に達 し, さらに 100 分程度でほぼ完全乾燥に近い状態にま で乾燥している.

マイクロ波減圧乾燥は，ホタテ貝柱内の水分に選択 的にエネルギーを供給できる利点がある. 一方, 温風 乾燥の水分への熱供給は, 表面からの熱伝導である. そのため, 温風乾燥では乾燥した表面層への加熱昇温 が避けられず，表面層の細胞が収縮して水分流路が狭 められ，物質移動の抵抗となることがわかっている(5). この観点からの比較のため, まず図 5 にホタテ貝柱内 部の水分分布の時間変化を示す. 図 5 (a)が温風乾燥,

(b)がマイクロ波乾燥の結果である. 横軸の番号 1 と 10 は，それぞれ貝柱の上面と下面に対応する。温風 乾燥の場合には表面部分の含水率が急速に低下するも のの, 内部の含水率はほとんど変化しておらず, 乾燥

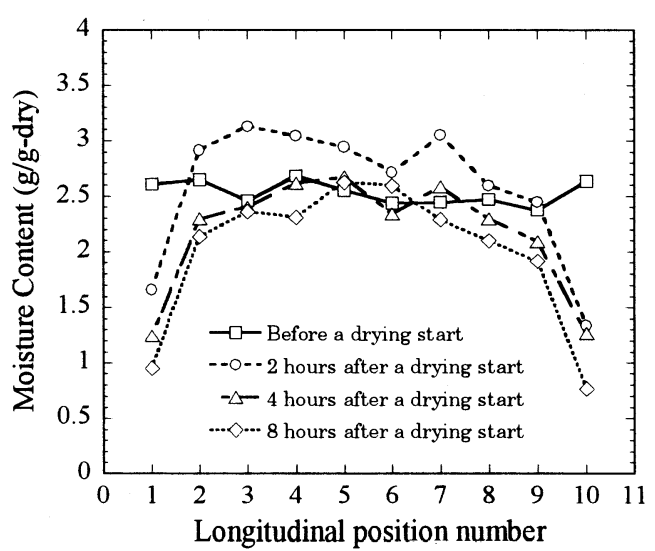

(a) Warm-air drying

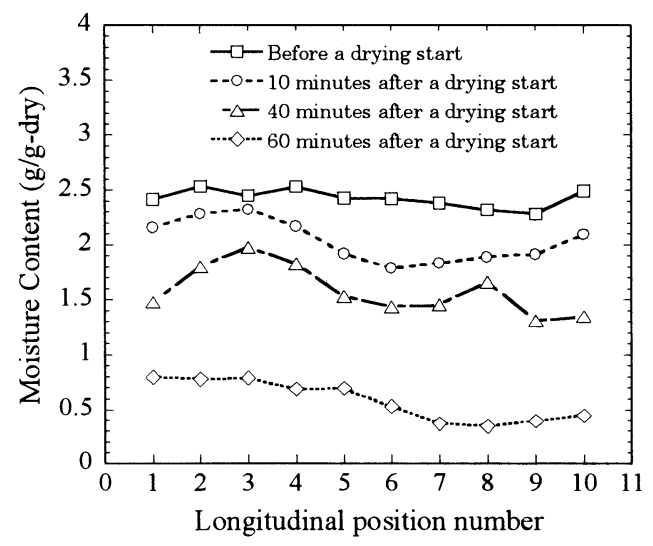

(b) Microwave drying

Fig. 5 Comparison of vertical distribution of moisture content inside the scallop between warm-air drying and microwave drying

速度の遅いことがわかる.これに対してマイクロ波減 圧乾燥の場合には, 乾燥過程全般において, 表面から 内部に至るまでほぼ一様に含水率が減少しているのが 確認される. これらの相違の理由を, 細胞の形態学的 変化から次に検討する.

図 6 の顕微鏡写真は, 乾燥前後の表面近傍の細胞の 様子である. 前報(5)でも述べたように，ホタテの貝柱 は笳繊維で構成されており, 筋繊維相互は結合組織で ある筋内膜で隔てられている(10). 図 6 の着色部が筀 繊維であり, 白色部が水分流路となりうる䇨緎維相互 の間隙である. 温風乾燥では, 表面の局部的乾燥のた めに図 6 (b)のように筋繊維細胞が収縮し，水分移動 の流路が狭められて乾燥速度が遅くなり, 内部に水分 が保有される結果となる. 一方, マイクロ波減圧乾燥 では, 図6(c)(d)に示すように, 表面層に過度の収縮は 

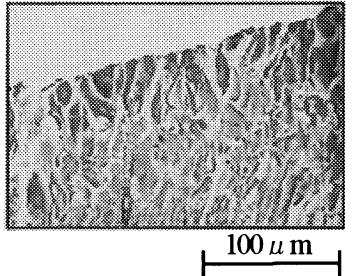

(a) Before drying

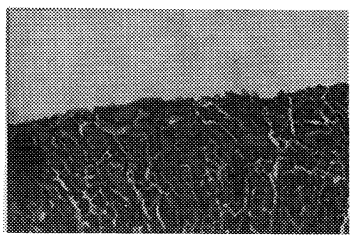

$100 \mu \mathrm{m}$

(c) 10 minutes microwave drying

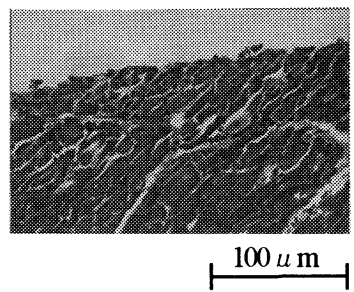

(d) 50 minutes microwave drying

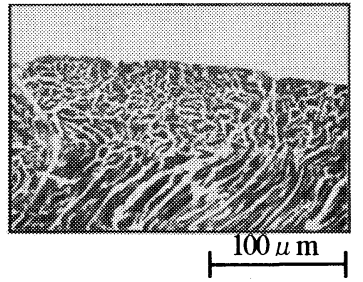

(b) 2 hours warm-air drying

Fig. 6 Microphotographs of tissue cells of scallop for a comparison of morphological change between pre- and post drying

認められず，細胞間の水分流路は維持されたままの状 態にある.このことが，水分が内部から表面へ常に移 動することが可能な状態にあり，マイクロ波による内 部へのエネルギー供給と相まって, 図 5 に示したよう に表面から内部に至るまで一様に乾燥が進む理由と考 えられる.さらに，温度上昇を抑えた常温近傍での乾 燥操作であるため, 温度上昇による細胞内外の浸透圧 増加を抑制でき，温風乾燥に見られた細胞の膨閏によ る細胞間流路の縮小を防ぐことができており，これら

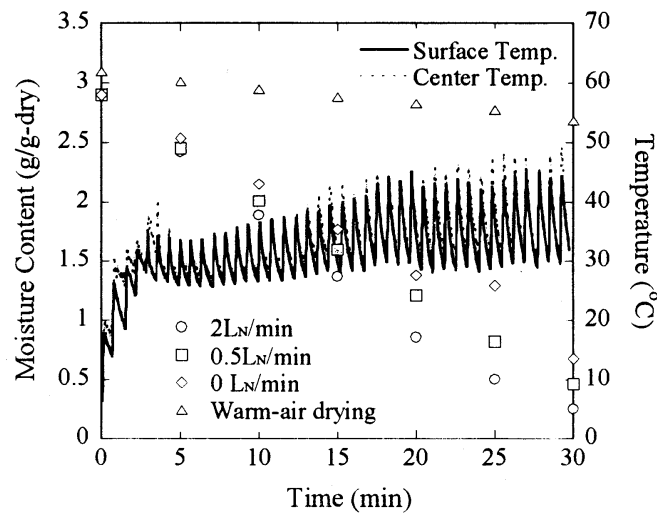

Fig. 7 Time transients of temperature and moisture content under $75 \mathrm{~W}$ irradiation at $6.66 \mathrm{kPa}$
の効果によって大幅に乾燥時間を短縮することができ たものと考える.

$3 \cdot 2$ 外気導入量の影響 次に, 図 3 に示すマイ ク口波の周期的な間欠照射を基に，乾燥室内に導入す る外気の影響を調べた結果について述べる.

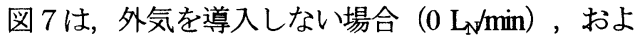
び外気を $0.5 \mathrm{~L} / \mathrm{min}$ と $2 \mathrm{~L} / \mathrm{min}$ の割合で導入した際の 含水率と温度の過渡変化を示したものである. このと きのマイクロ波の出力は, 時間平均で 75W(図 3-C)で ある。温度については，一例として外気流入量 $2 \mathrm{~L}_{\mathbb{N}} / \mathrm{min}$ の場合を示している. この結果から，外気の 流入量が多いほど, 乾燥が促進されていることがわか る. その程度は, 外気を導入しない場合に 30 分でお よそ 0.7 の含水率になるのに対し, 外気を $2 \mathrm{~L}_{\mathbb{N}} / \mathrm{min}$ の 割合で導入すると, 同じ含水率には 8 分程度早く到達 し, 30 分では約 0.25 の含水率にまで乾燥している. 温度は, マイクロ波照射開始後 3 分程度で約 $30^{\circ} \mathrm{C}$ に まで上昇し，その後しばらくは乾燥室内圧力 $6.60 \mathrm{kPa}$ に対する飽和温度（約 $38^{\circ} \mathrm{C}$ ) 以下に保たれるが，含 水率が 1.5 程度になると温度が徐々に上昇しているよ うに見受けられる。しかし，40ㅇいし $50^{\circ} \mathrm{C}$ 以下に 保たれており, 品質面からの問題を生じる可能性は極 めて低い.

次に, 含水率と蒸発速度との関係を示寸乾燥特性曲 線によって外気導入の効果を検討する. 図 8 は, 図 7 の実験結果から乾燥特性を求めたものである. 含水率 が $1 \sim 1.5$ 以上の領域では, 蒸発乾燥速度はほぼ一定 であり，いわゆる恒率乾燥の期間であることがわかる. これより少ない含水率では, 蒝発速度が含水率の低下 とともに減少しており，減率乾燥期間となっている。

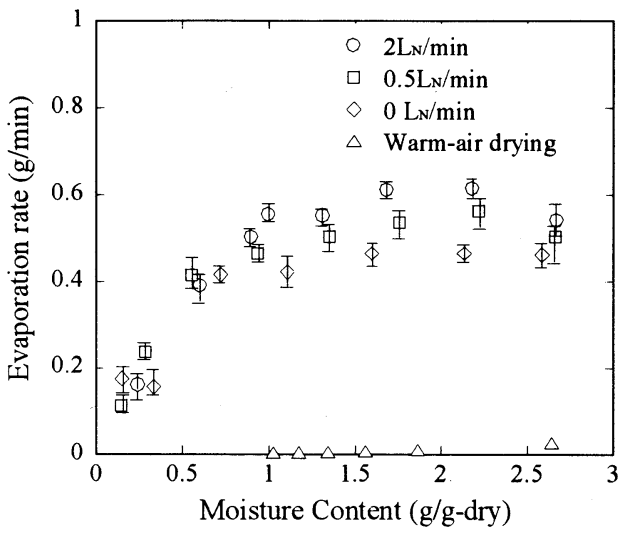

Fig. 8 Effect of air flow-rate on drying characteristics curve at $75 \mathrm{~W}$ and $6.66 \mathrm{kPa}$ 
また, この減率乾燥が始まる時の含水率は, 図 7 に示 したように温度上昇が見られる含水率とほぼ一致して おり，このことからも含水率 1 ～1.5 に限界含水率が あると判断される. ここで, 外気導入の効果に関して 明らかになるのは, その効果が恒率乾燥期間において はっきりと現れていることである.つまり，外気導入 量とともに恒率乾燥期間の蒸発速度が上昇し, 外気導 入量 $2 \mathrm{~L}_{\mathrm{V}} \mathrm{m} \min$ の蒸発率は導入しない場合に比べて約 1.3 倍に大きくなっている. 気体の導入は, 減圧下での水 分のキャリアガスとしての作用から乾燥容器内の相対 湿度を下げるとともに, 被乾燥体表面の濃度境界層を 薄くすることによって蒸発乾燥を促進していると考え る. 減率乾燥期間においては内部抵抗が物質輸送に支 配的となり, また蒸発量も低下することから, 外気導 入の効果は低减することになる. したがって，外気導 入は恒率乾燥期間における乾燥促進に効果的であると 言える. ただし, 気体の導入は真空ポンプの負荷を増 すことになるので, その量には制限がある.

\section{$3 \cdot 3$ マイクロ波照射制御及びガス導入による乾} 燥促進一般に, 恒率乾燥期間では供給熱量と蒸 発による潜熱輸送とが釣り合い，被乾燥体の温度変化 は生じない. したがって, 水分の十分にある乾燥初期 においては，ある程度多くのエネルギーを供給しても 温度上昇はなく, 乾燥速度を大きくすることが可能で ある. そこで, 本マイクロ波減圧乾燥においても，マ イクロ波照射量を変えた実験を行っている. 図 9 は, 外気導入量 $2 \mathrm{~L} / \mathrm{min}$, 圧力 $6.66 \mathrm{kPa}$ の状態で, マイク 口波の照射出力を図 2 のパターンに従って変えたとき の結果である. やはり恒率乾燥期間において, マイク 口波照射のエネルギーが高いほど蒸発速度は大きく， $100 \mathrm{~W}$ の場合は $42 \mathrm{~W}$ よりもおよそ 26 倍となってい る. 一方, 减率乾燥期間においてはマイクロ波照射量 の影響はみられず，過度のエネルギー供給は無意味で あることがわかる.ここで限界含水率に着目すれば, マイクロ波照射量とともに限界含水率がわずかに減少 しているように思われる. マイクロ波を用いた場合に, 被乾燥体内部で蒸発が生じ, 水分を表面まで運ぶポン プ効果が期待されるという報告(11)もあり，そのために 恒率乾燥期間が拡大された可能性もあるのではないか と考えている. 図5 の水分分布が一様に減少している こととの関連からも興味深く, 今後の詳細な検証が必 要である.

本報では，図9の結果に基づき，温度上昇の心配の ない恒率乾燥期間においてはエネルギー投入量を大き くし，温度上昇を考虑しなければならない減率乾燥期 間においてはエネルギ一量を減少することにより，効

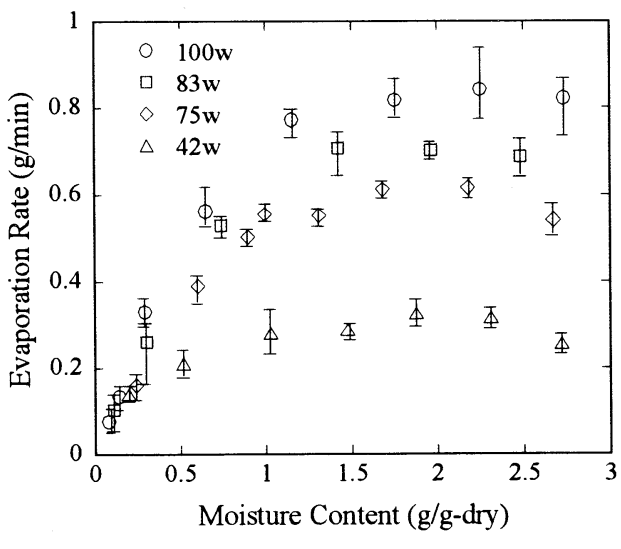

Fig. 9 Effect of microwave power on evaporation rate at $2 \mathrm{~L}_{\mathrm{N}} / \mathrm{min}$ air flow and $6.66 \mathrm{kPa}$.

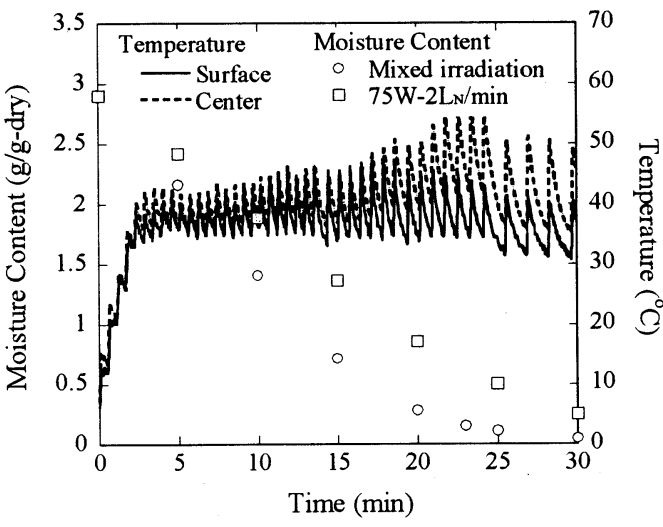

Fig. 10 Transients of moisture content and temperatures for mixed irradiation pattern of microwave at $2 \mathrm{~L}_{\mathrm{N}} / \mathrm{min}$ air flow and $6.66 \mathrm{kPa}$.

率的かつ高品位なマイクロ波減圧乾燥が可能なことを 示寸. 図 10 は, 限界含水率を 1 程度と想定し, 初め の 15 分間に $100 \mathrm{~W}$ (図 2-A)の照射を, 15〜20 分間に $83 \mathrm{~W}$ (図 2-B)，20 23 分間で $75 \mathrm{~W}$ (図 2-C)，23〜30 分 間で $42 \mathrm{~W}$ (図 2-D)の照射を行ったときの含水率と温度 の過渡変化である. 貝柱の中心部温度は $50^{\circ} \mathrm{C}$ 超え ている部分が一部あるが, 表面温度はほぼ $40^{\circ} \mathrm{C}$ 以下 に保たれており，温度上昇が抑えられていることがわ かる. また, 乾燥速度を先に示した $75 \mathrm{~W} の$ 照射パタ ーンのみの場合と比較すると明らかに早くなっており, 約 0.25 の含水率になるまでの時間がおよそ 10 分短縮 されている. 恒率乾燥期間では照射量を多くし, 減率 乾燥期間では減らすことにより, 蒸発潜熱一の効率的 な転換，ならびに温度上昇を抑えた良質・高品位な乾 燥を実現でき，乾燥時間も短縮することができる。 


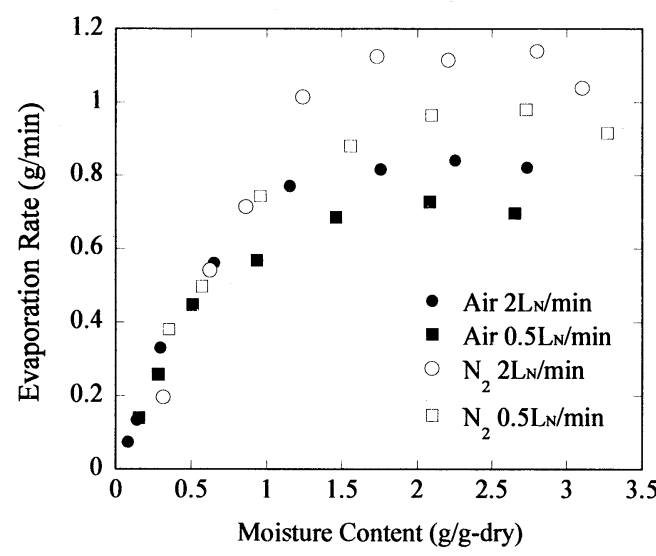

Fig. 11 Effect of $\mathrm{N}_{2}$ gas on drying rate at $100 \mathrm{~W}$

最後に, 乾燥室に導入する気体として, 外気の代わ りに窒素ガスを用いてマイクロ波減圧乾燥を行った.

これは，非酸化の雲囲気条件とすることができること， および湿分を含まないために乾燥が促進されることを 期待するものである．図 11 に，100Wのマイクロ波照 射を対象とし, 乾燥特性曲線としてその結果を示す. 减率乾燥期間における差は無いものの, 恒率乾燥期間 においては乾燥速度が大きくなっており，窒素ガスの 利用は外気を導入する場合と比較して約 20\%程度の蒸 発速度促進効果があった．これは，気体側の物質伝達 が促進されるためと理解でき，同様の効果は窒素ガス だけではなく，例えば乾燥空気を導入することによっ ても得られると考える.

\section{4. 結 論}

マイクロ波の間欠照射による温度制御，ならびに 外気を導入した減圧条件化での乾燥は，被乾燥体に熱 的ダメージを与えない常温での高品位な乾燥を可能と し，しかも今までにない短時閒での乾燥を実現できる. さらに，恒率乾燥期間においてマイクロ波出力を大き くし, 減率乾燥期間において徐々にマイクロ波出力を 低減することにより，乾燥時間を短縮することができ， 同時にエネルギー的にも無駄のない効率的な乾燥方法 とすることが可能である. また, 乾燥室内への気体の 導入は恒率乾燥期間において特に有効な方法であり, 外気のほかにも窒素ガスなどの不活性ガスを供給する
ことにより，酸化を抑え，乾燥も促進することができ る.

なお, 本研究は日本学術振興会科学研究費補助金 [基盤研究(B)17360099]，および科学技術振興機構プ ラザ福岡育成研究調査の補助を受けて行った。 また, 実験に協力された元本学大学院学生の川原圭司君に謝 意を表す.

\section{文献}

(1) Irzyniec, Z., et al., Freeze-drying of the Black Currant Juice, Drying Technology, Vol.13, No.1 (1995), pp.417-424.

(2) Chou, S.K. and Chua, K.J., New Hybrid Drying Technologies for Heat Sensitive Foodstuffs, Trends in Food Science \& Technology., Vol.12 (2001), pp.359-369.

(3) Ratti, C., Hot Air and Freeze-drying of High-value Foods: A Review, Journal of Food Engineering, Vol.49, (2001), pp.311-319.

(4) Kumar, P. and Mishra, H.N., Yoghurt Powder - A Review of Process Technology, Storage and Utilization, Food and Bioproducts Processing, Vol.82, No. C2, (2004), pp.133-142.

(5) Hayashi, T. et al., Heat and Mass Transfer in Warm-air Drying of Seafood, Transactions of the Japan Society of Mechanical Engineers, Series B, Vol. 72, No. 715, (2006), pp.723-729.

(6) Shivhare, U.S., et al., Microwave Drying of Corn. 3. Constant Power, Intermittent Operation, Transactions of the American Society of Agricultural Engineers, Vol.35, No.3 (1992), pp.959-962.

(7) Drouzas, A.E. and Schubert, H., Microwave Application in Vacuum Drying of Fruits, Journal of Food Engineering, Vol.28, No.2 (1996), pp.203-209.

(8) Gunasekaran, S., Pulsed Microwave-vacuum Drying of Food Materials, Drying Technology, Vol.17, No.3 (1999), pp.395-412.

(9) Cui, Z., et al., Microwave-vacuum Drying Kinetics of Carrot Slices, Journal of Food Engineering, Vol.65, (2004), pp.157-164.

(10) Suyama, M. and Konos, S., Marine Food Science (in Japanese), Koseisha Koseikaku, (1999), pp.8.

(11) Turner, I.W. and Jolly, P., Combined Microwave and Convective Drying of a porous Material, Drying Technology -An International Journal ,Vol. 9, (1991), pp.12091270. 